\title{
Analisis Pengendalian Persediaan Bahan Baku PVC Compound Menggunakan Metode ABC Analisis dan EOQ Berbasis POM-QM for Windows V5.2
}

\author{
Amin Widodo*, Makhsun Makhsun, Achmad Hindasyah \\ Magister Komputer, Teknik Informatika, STMIK Eresha, Tangerang Selatan, Indonesia, 15310 \\ *e-mail: aminwidodo80024@gmail.com \\ Submitted Date: June $07^{\text {th }}, 2020$ \\ Revised Date: June $26^{\text {th }}, 2020$ \\ Reviewed Date: June $17^{\text {th }}, 2020$ \\ Accepted Date: June $30^{\text {th }}, 2020$
}

\begin{abstract}
PT. Sinarmonas Industries is engaged in the Manufacture industry as a precision cable company that manufactures PVC Compound itself, the company is committed to always maintaining customer satisfaction by implementing ISO 9001 2015. In an effort to increase customer satisfaction the company experiences constraints namely determining raw materials that require special monitoring so that more inventory control efficient. The research method used is the ABC Analysis and Economic Order Quantity (EOQ) method with the help of POM-QM Information Technology Tools for Windows V5.2 this software is to assist companies in solving problems faced by operations management. The results of the study using the ABC Analyst method show that raw materials that require very strict monitoring, namely PVC 66, stabilizer, and PVC 71 of the three raw materials, are calculated using the Economic Order Quantity (EOQ) method, the company has the benefit of saving the cost of raw material inventory, namely PVC 66 an average of $R p 96,321,440.00$ or companies can save inventory costs by $44 \%$, Stabilizer raw materials an average of $R p$ 4,634,959.00 or companies can save inventory costs by 57\%, PVC raw materials 71 an average of $R p$ 49,304 .566.00 or a company can save $38 \%$ in costs.
\end{abstract}

Keywords: ABC Analisys; EOQ; POM-QM For Windows; Pamulang University

\section{Abstrak}

PT. Sinarmonas Industries bergerak di bidang industri Manufacture sebagai perusahaan kabel presisi yang memproduksi PVC Compound sendiri, perusahan berkomitmen selalu menjaga kepuasaan pelanggan yaitu dengan menerapkan ISO 9001 2015. Dalam upaya meningkatkan kepuasan pelanggan, perusahaan mengalami kendala yaitu menentukan bahan baku yang membutuhkan monitoring khusus agar pengendalian persediaan lebih efisien. Metode penelitian yang digunakan yaitu metode ABC Analisys dan Economic Order Quantity (EOQ) dengan dengan bantuan Tools teknologi informasi POMQM For Windows V5.2 perangkat lunak ini untuk membantu perusahaan dalam menyelesaikan permasalahan yang di hadapi manajemen operasi. Hasil penelitian menggunakan metode ABC Analisys menujukan bahan baku yang membutuhkan monitoring sangat ketat yaitu PVC 66, Stabilizer, dan PVC 71 dari ketiga bahan baku tersebut di lakukan perhitung menggunakan Metode Economic Order Quantity (EOQ) perusahaan mendapat keuntungan penghematan biaya persediaan bahan baku yaitu PVC 66 ratarata $\mathrm{Rp} 96.321 .440,00$ atau perusahaan dapat menghemat biaya persediaan senilai $44 \%$, bahan baku

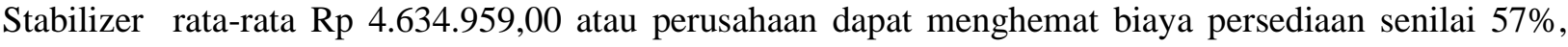
bahan baku PVC 71 rata-rata Rp 49.304.566.00 atau perusahaan dapat menghemat biaya senilai 38\%.

Kata Kunci: ABC Analisys; EOQ; POM QM For Windows; Universitas Pamulang

\section{Pendahuluan}

PT. Sinarmonas Industries didirikan pada tahun 1993 yang bergerak di bidang industri Manufacture sebagai perusahaan kabel presisi yang membuat bahan baku selubung kabel sendiri yang disebut PVC Compound. PVC Compound yang di produksi telah melalui proses pemeriksaan kualitas sangat ketat di laboratorium untuk 
memenuhi hasil sesuai dengan yang telah dipersyaratkan oleh Customer. Produk yang dihasilkan dipastikann telah memenuhi standard lokal maupun ekspor dan telah memenuhi standard Restriction Of Hazardous Substances (RoHS) yang dipersyaratkan pasar Uni Eropa. PT.Sinarmonas Industries juga melaksanakan pengelolaan keselamatan dan kesehatan kerja dengan cara menerapkan Sistem Manajemen Keselamatan dan Kesehatan Kerja (SMK3). untuk meminimalisasi penyakit akibat kerja dan nihilnya ancaman keamanan serta serta kecelakaan kerja.

Sistem manajemen mutu ISO 9001:2015 telah diterapkan di PT. Sinarmonas Industries dengan konsisten memberikan pelayanan dan hasil produk yang berkualitas. Sistem manajemen mutu diterapkan untuk meyakinkan konsumen bahwa produk yang dihasilkan perusahaan mampu memenuhi persyaratan dari pembeli dan meningkatkan loyalitas konsumen terhadap Perusahaan (Ramadhany, 2017). Dalam upaya meningkatan kepuasan pelanggan perusahaan mengharapkan selisih persentase antara kebutuhan dan pembelian hanya $15 \%$ untuk stock persedian. Berikut ini adalah Hasil observasi kebutuhan bahan baku PVC Compound dapat dilihat pada Tabel 1. Sebagai berikut.

Tabel 1 Kebutuhan Bahan Baku PVC Compound

\begin{tabular}{|r|l|r|r|r|c|}
\hline NO & $\begin{array}{c}\text { JENIS } \\
\text { MATERIAL }\end{array}$ & \multicolumn{1}{|c|}{ Kebutuhan } & \multicolumn{1}{|c|}{ Pembelian } & Selisih Actual & $\begin{array}{c}\text { Persentase } \\
\%\end{array}$ \\
\hline 1 & PVC 71 & $\mathbf{9 0 . 6 4 3 . 1 7 9}$ & $\mathbf{1 1 1 . 0 6 0 . 0 0 0}$ & 20.256 .821 & $22 \%$ \\
\hline 2 & PVC 66 & 220.832 .060 & 278.180 .000 & 57.227 .940 & $26 \%$ \\
\hline 3 & Plasticizer P & 6.902 .092 & $\mathbf{8 . 8 4 0 . 0 0 0}$ & 1.857 .908 & $26 \%$ \\
\hline 4 & Plasticizer T & 1.098 .088 & 1.504 .000 & 389.912 & $31 \%$ \\
\hline 5 & Plasticizer IP & 1.110 .277 & 1.388 .000 & 261.723 & $24 \%$ \\
\hline 6 & Plasticizer 52 & 1.164 .983 & 1.469 .000 & 292.017 & $27 \%$ \\
\hline 7 & Filler 10 C & $\mathbf{1 0 . 4 9 7 . 5 5 0}$ & 13.150 .000 & 2.577 .450 & $24 \%$ \\
\hline 8 & Stabilizer CZ & 61.008 & $\mathbf{8 0 . 0 0 0}$ & 17.492 & $30 \%$ \\
\hline 9 & Stabilizer TB & 1.098 .633 & 1.300 .000 & 201.367 & $20 \%$ \\
\hline 10 & Stabilizer & 114.054 & 153.000 & 36.946 & $32 \%$ \\
\hline 11 & Lubricant 15 & 141.239 & 177.300 & 34.061 & $23 \%$ \\
\hline 12 & Lubricant 16A & 56.194 & 71.500 & 13.306 & $24 \%$ \\
\hline 13 & Lubricant 17A & 25.688 & 33.400 & 6.512 & $25 \%$ \\
\hline 14 & Lubricant 20 & 28.072 & 37.500 & 7.928 & $28 \%$ \\
\hline 15 & Filler CY & 229.173 & 291.000 & 58.327 & $25 \%$ \\
\hline 16 & Pigment B & 94.271 & 123.500 & 27.729 & $29 \%$ \\
\hline 17 & Pigment TI & 31.036 & 39.500 & 7.464 & $26 \%$ \\
\hline 18 & Filler F-1 & 1.402 .206 & 1.735 .000 & 332.794 & $25 \%$ \\
\hline 19 & Lubricant 24 & 28.352 & 37.000 & 7.648 & $27 \%$ \\
\hline
\end{tabular}

Berdasar tabel di atas permasalahan dapat di uraikan bahwa perusahaan membutuhkan metode untuk klasifikasi bahan baku dan memberikan prioritas pada bahan baku yang berdasarkan tingkat penyerapan modal dan dimonitoring secara ketat, perusahaan perlu menerapkan perencanaan dan pengendalian persediaan untuk mencapai tujuan yaitu persentase selisih antara pembelian dan kebutuhan dapat di kendalikan sesuai dengan target perusahaan.

Kerugian yang terjadi saat ini investasi pada bahan baku terlalu tingginya beban biaya pemesanan dan biaya menyimpan untuk pemeliharaan bahan selama penyimpanan sehingga biaya yang dikeluarkan perusahaan tidak efisien dan persediaan belum optimum.

Persediaan yang menjadi salah satu aset terpenting dalam perusahaan serta dapat mempengaruh jumlah biaya operasi diperusahaan, pengendalian persediaan dan perencanaan merupakan suatu kegiatan penting yang harus mendapatkan perhatian khusus dari manajemen. Ketidakpastian dalam menentukan jumlah pembelian bahan baku yang tidak optimal dan keterlambatan pemesanan bahan baku diakibatkan oleh tidak memiliki penjadwalan pemesanan yang ( Apriyani \& Muhsin, 2017).

Penelitian menggunakan POM-QM For Windows untuk penyelesaian permasalahan manajemen produksi dan operasi, output dari penelitian yaitu klasifikasi bahan baku sesuai dengan tingkat penyerapan modal mulai dari persentase penyerapan modal tertinggi ke paling rendah, persedian lebih optimum, diketahui jumlah pemesanan ekonomis atau disebut EOQ, dan menghasilkan titik pemesanan kembali dengan demikian biaya yang dikeluarkan perusahaan efisien.

\section{Metodologi}

Jenis data yang digunakan dalam penelitian ini yaitu data kuantitatif, Jenis penelitian diskriptif yang hanya memfokuskan pada masalah-masalah actual, sumber data yang digunakan adalah data primer yang didukung dengan data sekunder untuk memperkaya hasil penelitian. Objek penelitian adalah bahan baku PVC Compound pada persediaan bahan baku di Inventory PT Sinarmonas Industries. data yang digunakan dalam penelitian yaitu pembeliaan bahan baku ,jumlah kebutuhan bahan baku, biaya persediaan, periode pemesanan, lead time.

\subsection{Definisi Persediaan}

Persediaan didefinisikan sebagai barang yang disimpan untuk digunakan atau dijual pada periode mendatang ( Roni , 2016). Persediaan dapat berbentuk bahan baku yang simpan untuk diproses, barang dalam proses pada proses manufaktur atau Work In Proses, barang jadi yang 
disimpan untuk dijual dan komponen yang sedang diproses.

Mengendalikan persediaan yang sesuai kebutuhan dapat dikatakan tepat merupakan hal yang cukup sulit. Apabila jumlah persediaan lebih besar mengakibatkan timbulnya dana menganggur yang besar atau dana yang mengendap di dalam persediaan, resiko kerusakan barang yang lebih besar dan meningkatnya biaya penyimpanan. Tapi, jika persediaan terlalu sedikit memiliki resiko terjadi kekurangan persediaan (stock out) karena barang tidak dapat didatangkan secara mendadak dan sebesar yang dibutuhkan, yang menyebabkan terhentinya proses produksi, tertundanya penjualan, bahkan kehilangan pelanggan ( Apriyani \& Muhsin, 2017).

\subsection{Fungsi Persediaan}

Beberapa fungsi persediaan bagi perusahaan adalah (Jay \& Barry, 2010).

1. Decouple atau memisahkan beberapa tahapan dari proses produksi. Sebagai contoh, jika persediaan sebuah perusahaan berfluktuasi, persediaan tambahan mungkin diperlukan untuk melakukan decouple proses produksi dari pemasok.

2. Melakukan "decouple" perusahaan dari fluktuasi permintaan dan menyediakan persediaan barang-barang yang akan memberikan pilihan bagi pelanggan. Persediaan seperti ini digunakan secara umum pada bisnis eceran.

3. Mengambil keuntungan dari melakukan pemesanan dengan sistem diskon kuantitas, karena dengan melakukan pembelian dalam jumlah banyak dapat mengurangi biaya pengiriman.

4. Melindungi perusahaan terhadap inflasi dan kenaikan harga.

\subsection{Biaya Dalam Persediaan}

Biaya-biaya yang ditimbulkan dalam persedian dapat dikelompokana sebagai berikut:

1. Biaya Pemesanan (Ordering Costs)

Biaya yang dikeluarkan perusahaan meliputi biaya proses pemesanan, formulir, administrasi pendukung termasuk biaya bongkar muat dan biaya pembeliaan.

2. Biaya penyimpanan (holding cost)

Biaya yang dikeluarkan perusahaan dalam menyimpan bahan baku di gudang meliputi penerangan, pemeliharaan, penambahan karyawan, kerusakan barang dan bunga yang harus dibayar modal tertanam dalam bahan baku yang disimpan.

3. Biaya penyetelan (setup cost)

Biaya yang dikeluarkan perusahaan terkait dengan persiapan dalam proses untuk membuat sebuah pemesanan misalkan mengganti peralatan, biaya dapat lebih efisien dengan pembayaran dan pemesanan secara online.

\subsection{Analisis Persedian Metode ABC Analisys}

Analisis ABC merupakan suatu analisis yang membagi persediaan ke dalam 3 kelas berdasarkan nilainya, yaitu menkategorikan ke dalam kelas A, B dan C. Kelas A untuk item-item yang nilainya tinggi (very importan), kela $\mathrm{B}$ untuk item-item yang nilainya sedang (less important) dan kelas C (least important) untuk item-item yang nilai rendah. Analisis $\mathrm{ABC}$ digunakan unutk menetapkan kebijakan prioritas atau fokus pada materi yang penting.

Tabel 2. Kebijakan Pengendalian Persediaan Bahan Baku Berdasarkan Klasifikasi ABC Analisys

\begin{tabular}{|l|c|c|c|}
\hline \multicolumn{1}{|c|}{ Deskripsi } & Kelas A & Kelas B & Kelas C \\
\hline \hline Fokus Perhatiaan & Utama & Sedang & Cukup \\
\hline Manajemen & - & - & - \\
\hline Pengendalian (Control) & Ketat & Sedang & Longgar \\
\hline Stock Pengaman & Jangka Pendek & Menengah & Jangaka Panjang \\
\hline Akurasi Pengaman & Tinggi & Sedang & Cukup \\
\hline Kebutuhan Perhitungan & Jangka Pendek & Menengah & Panjang \\
\hline
\end{tabular}

\subsection{Analisis Persediaan Metode Economic Order Quantity (EOQ)}

Jumlah pesanan ekonomis (economic order quantity(EOQ) merupakan salah satu model klasik, diperkenalkan oleh FW Harris pada tahun 1914, tetapi paling dikenal dalam teknik pengendaliaan persediaan. Economic Order Quantity (EOQ) merupakan suatu teknik pengendalian persediaan bahan baku untuk menentukan jumlah pesanan yang ekonomis setiap kali pemesanan dengan frekuensi yang telah ditentukan serta jadwal titik pemesanan kembali dilakukan. Model kuantitas pesanan ekonomis Economic Order Quantity adalah salah satu teknik kontrol persediaan yang meminimalkan biaya total dari pemesanan dan penyimpanan (Jay \& Barry, 2010). 


\subsection{Definisi POM-QM For Windows}

Program POM-QM For Windows merupakan program komputer yang didesain untuk menyelesaikan persoaalan secara matematis yang berhubungan dengan metode kuantitatif, ilmu manajerial, dan riset operasi ( Nisa , 2019).

POM-QM for Windows merupakan paket yang dapat digunakan untuk melengkapi Ilmu Keputusan. termasuk Manajemen Produksi dan Operasi, metode kuantitatif, ilmu manajemen, atau riset operasi (Weiss, 2011).

Untuk install POM-QM for Windows spesifikasi hardwere sebagai berikut:

1. Processor AMD E2-3800 APU with Radeon (TM) HD Graphics $1.30 \mathrm{GHz}$.

2. Installed Memory (RAM), 2.00 GB (1,44 usable).

3. System type, 64-bit Operating system, x64based processor

4. Home, Windows 10.

5. Storage, 500 GB HDD.

Berikut tampilan perangkat lunak POM-QM for Windows dapat dilihat pada Gambar 1.

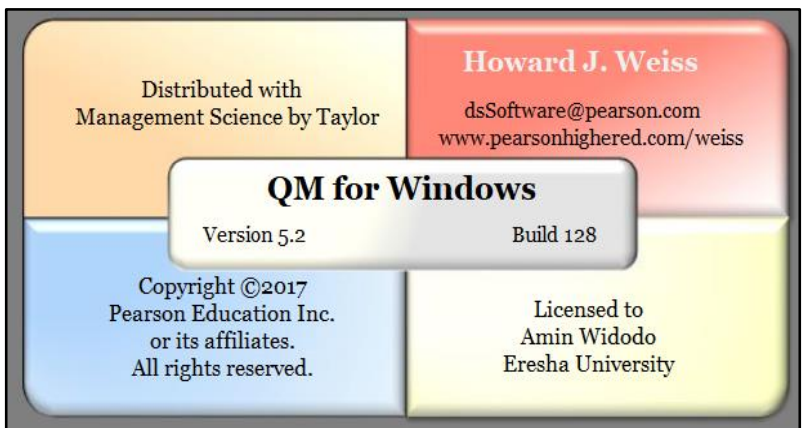

Gambar 1. Tampilan POM-QM For Windows

\subsection{Flow Chart Penelitian}

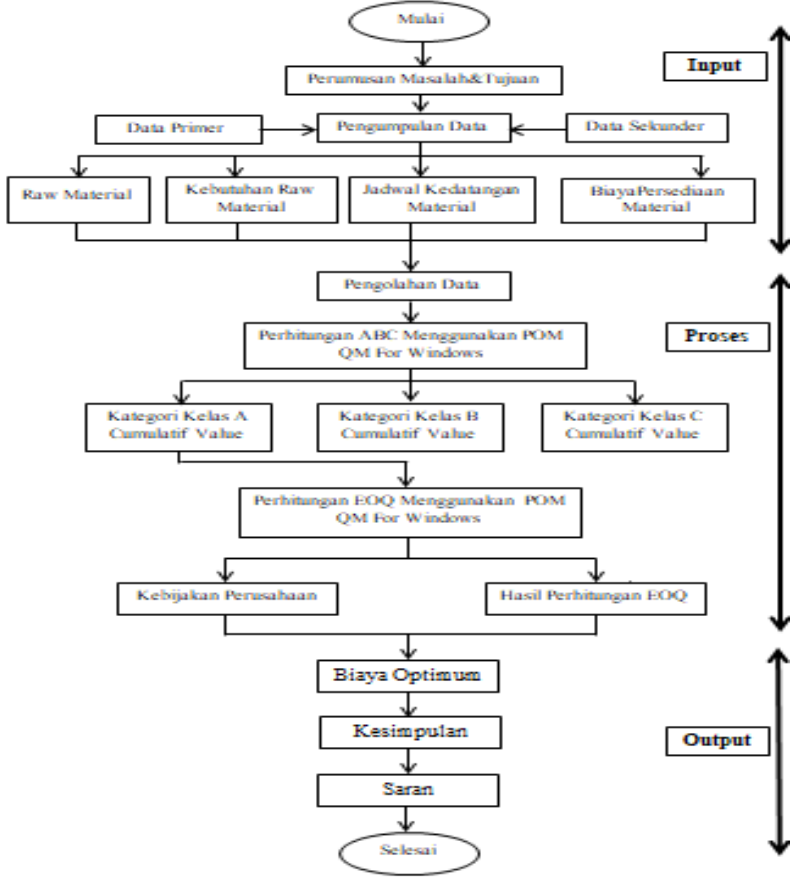

Gambar 2. Flow Chart penelitian

\section{Hasil dan Pembahasan}

3.1 Proses Pengolahan Data Bahan Baku Metode ABC Analisys Menggunakan POM-QM For Windows

Proses pengolahan data yang dilakukan peneliti adalah langkah-langkah untuk menyelesaiakan perhitungan $\mathrm{ABC}$ Analisys menggunakan Tools teknologi informasi POMQM For Windows V5.2, yaitu sebagai berikut: 1. Data Material yang akan di diproses.

Tabel 3. data kenutuhan bahan baku PVC Compound

\begin{tabular}{|c|c|c|c|c|c|c|}
\hline \multirow{2}{*}{ No } & \multirow{2}{*}{$\begin{array}{c}\text { JENIS } \\
\text { MATERIAL }\end{array}$} & \multicolumn{4}{|c|}{ TOTAL 2015-2019 } & \multirow{2}{*}{$\begin{array}{c}\mathrm{Harga} \\
/ \mathbf{k g}\end{array}$} \\
\hline & & Kebutuhan & Pembelian & Selisih Actual & $\begin{array}{c}\text { Rata-rata } \\
\text { Persentase } \\
\%\end{array}$ & \\
\hline 1 & PVC 71 & 90.643 .179 & 111.060 .000 & 20.256 .821 & $22 \%$ & 35300 \\
\hline 2 & Plasticizer P & 6.902 .092 & 8.840 .000 & 1.857 .908 & $26 \%$ & 29300 \\
\hline 3 & Plasticizer T & 1.098 .088 & 1.504 .000 & 389.912 & $31 \%$ & 27800 \\
\hline 4 & Plasticizer IP & 1.110 .277 & 1.388 .000 & 261.723 & $24 \%$ & 29200 \\
\hline 5 & \begin{tabular}{|l|} 
Plasticizer 52 \\
\end{tabular} & 1.164 .983 & 1.469 .000 & 292.017 & $27 \%$ & 11800 \\
\hline 6 & Filler $10 \mathrm{C}$ & 10.497 .550 & 13.150 .000 & 2.577 .450 & $24 \%$ & 2700 \\
\hline 7 & Stabilizer CZ & 61.008 & 80.000 & 17.492 & $30 \%$ & 30500 \\
\hline 8 & Stabilizer TB & 1.098 .633 & 1.300 .000 & 201.367 & $20 \%$ & 39800 \\
\hline 9 & Stabilizer & 114.054 & 153.000 & 36.946 & $32 \%$ & 36750 \\
\hline 10 & Lubricant 15 & 141.239 & 177.300 & 34.061 & $23 \%$ & 14500 \\
\hline 11 & Lubricant 16A & 56.194 & 71.500 & 13.306 & $24 \%$ & 48400 \\
\hline 12 & Lubricant 17A & 25.688 & 33.400 & 6.512 & $25 \%$ & 63900 \\
\hline 13 & PVC 66 & 220.832 .057 & 278.180 .000 & 57.227 .940 & $26 \%$ & 35500 \\
\hline 14 & Lubricant 20 & 28.072 & 37.500 & 7.928 & $28 \%$ & 25500 \\
\hline 15 & Filler $\mathrm{CY}$ & 229.173 & 291.000 & 58.327 & $25 \%$ & 3500 \\
\hline 16 & Pigment B & 94.271 & 123.500 & 27.729 & $29 \%$ & 20700 \\
\hline 17 & \begin{tabular}{|l} 
Pigment TI \\
\end{tabular} & 31.036 & 39.500 & 7.464 & $26 \%$ & 40300 \\
\hline 18 & \begin{tabular}{|l|} 
Filler F-1 \\
\end{tabular} & 1.402 .206 & 1.735 .000 & 332.794 & $25 \%$ & 23100 \\
\hline 19 & Lubricant 24 & 28.352 & 37.000 & 7.648 & $27 \%$ & 28700 \\
\hline
\end{tabular}


2. Buka POM-QM For Windows V5.2 pilih module inventory.

3. Pilih file new sehingga muncul seperti gambar 3. Input Title dengan judul hasil analisys bahan bahan baku PVC Compound. Number of item ada 19 item yang akan diteliti kemudian klik Ok.

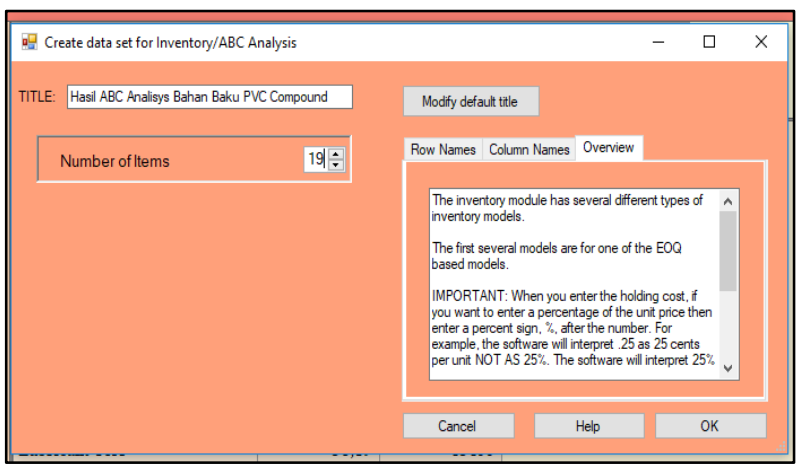

Gambar 3. Tampilan Create data set inventory

4. Masukan data sesuai dengan kendala, permasalahan dapat diselesaikan dengan solve.

\begin{tabular}{||l|r|r|}
\hline \multicolumn{3}{||}{ Hasil ABC Analisys Bahan Baku PVC Compound } \\
\hline Item name & Demand & Unit price \\
\hline PVC 71 & 90,64 & 35300 \\
\hline Plasticizer P & 6,9 & 29300 \\
\hline Plasticizer T & 1,1 & 27800 \\
\hline Plasticizer I & 1,11 & 29200 \\
\hline Plasticizer 52 & 1,16 & 11800 \\
\hline Filler 10 C & 10,5 & 2700 \\
\hline Stabilizer CZ & 61,01 & 30500 \\
\hline Stabilizer TB & 1,1 & 39800 \\
\hline Stabilizer & 114,05 & 36750 \\
\hline Lubricant 15 & 141,24 & 14500 \\
\hline Lubricant 16A & 56,19 & 48400 \\
\hline Lubricant 17A & 25,69 & 63900 \\
\hline PVC 66 & 220,83 & 35500 \\
\hline Lubricant 20 & 28,07 & 25500 \\
\hline Filler CY & 229,17 & 3500 \\
\hline Pigment B & 94,27 & 20700 \\
\hline Pigment TI & 31,04 & 40300 \\
\hline Filler F-1 & 1,4 & 23100 \\
\hline
\end{tabular}

Gambar 4. Input data

5. Hasil klasifikasi Bahan Baku Metode ABC Menggunakan POM-QM For Windows

Berikut merupakan hasil perhitungan metode ABC Analisys dengan bantuan POM-QM For Windows yang hasilnya adalah klasifikasi bahan baku sesuai kelas, A dengan penyerapan modal tertinggi, B dengan penyerapan modal sedang, dan $\mathrm{C}$ dengan penyerapan rendah. Penelitian akan dilanjutkan hanya pada bahan baku yang masuk prioritas yaitu kelas A.

\begin{tabular}{|c|c|c|c|c|c|c|}
\hline \multicolumn{7}{|c|}{ Hasil ABC Analisys Bahan Baku PVC Compound Solution } \\
\hline Item name & Demand & Price & $\begin{array}{l}\text { Dollar } \\
\text { Volume }\end{array}$ & $\begin{array}{l}\text { Percent of } \\
\text { S-Vol }\end{array}$ & $\begin{array}{l}\text { Cumultv } \\
\text { s-vol \% }\end{array}$ & Category \\
\hline PVC 66 & 220,83 & 35500 & 7839536 & 26,65 & 26,65 & A \\
\hline Stabilizer & 114,05 & 36750 & 4191485,0 & 14,25 & 40,9 & A \\
\hline PVC 71 & 90,64 & 35300 & 3199698,0 & 10,88 & 51,77 & A \\
\hline Lubricant $16 \mathrm{~A}$ & 56,19 & 48400 & 2719790,0 & 9,25 & 61,02 & B \\
\hline Lubricant 15 & 141,24 & 14500 & 2047966,0 & 6,96 & 67,98 & B \\
\hline Pigment B & 94,27 & 20700 & 1951410,0 & 6,63 & 74,61 & B \\
\hline Stabilizer CZ & 61,01 & 30500 & 1860744 & 6,33 & 80,94 & c \\
\hline Lubricant $17 \mathrm{~A}$ & 25,69 & 63900 & 1641463,0 & 5,58 & 86,52 & c \\
\hline Pigment TI & 31,04 & 40300 & 1250751,0 & 4,25 & 90,77 & c \\
\hline Lubricant 24 & 28,35 & 28700 & 813702,4 & 2,77 & 93,54 & c \\
\hline Filler CY & 229,17 & 3500 & 802105,5 & 2,73 & 96,26 & c \\
\hline Lubricant 20 & 28,07 & 25500 & 715836 & 2,43 & 98,7 & c \\
\hline Plasticizer P & 6,9 & 29300 & 202228,6 & ,69 & 99,38 & c \\
\hline Stabilizer TB & 1,1 & 39800 & 43700,4 &, 15 & 99,53 & c \\
\hline Plasticizer IP & 1,11 & 29200 & 32412 & ,11 & 99,64 & c \\
\hline Filler F-1 & 1,4 & 23100 & 32386,2 & 11 & 99,75 & c \\
\hline
\end{tabular}

Gambar 5. Hasil klasifikasi kelas ABC Analisys POM-QM For Windows

Jumlah item yang di analisis adalah 19 bahan baku, dari hasil perhitungan ABC Analisys menggunakan Tools teknologi informasi POMQM For Windows masuk kategori A didapat 3 item, 6 item kategori B, dan 10 item kategori C, dapat dilihat pada Gambar 6 Persentase Analisis ABC Analisys sebagai berikut.

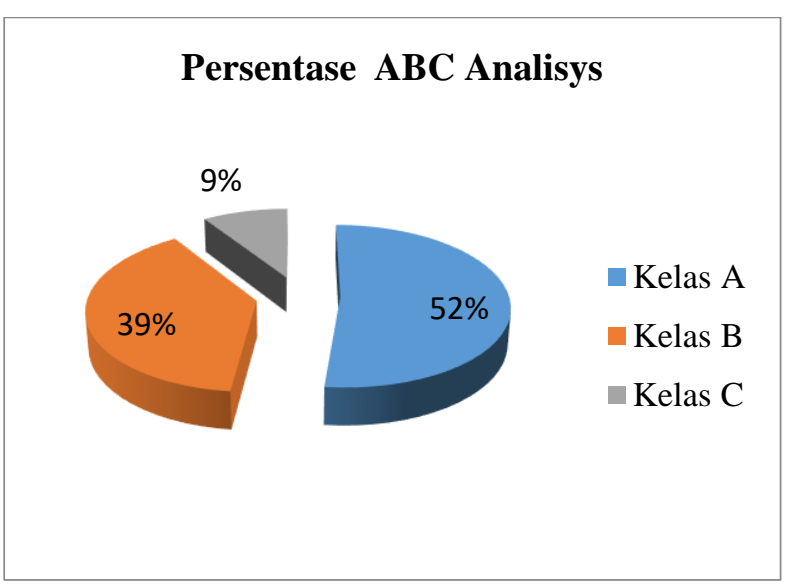

Gambar 6. Persentase ABC Analisys

Berdasarkan hasil klasifukasi ABC Analisys hanya ada 3 bahan baku yang akan dilakukan perhitungan metode EOQ, rincian kebutuhan bahan baku yaitu sebagai berikut: 
Tabel 4. Rincian kebutuhan PVC 66 periode 2015-2019

\begin{tabular}{|l|c|c|c|c|c|}
\hline \multirow{3}{*}{ Bulan } & \multicolumn{5}{|c|}{ Tahun } \\
\cline { 2 - 7 } & $\mathbf{2 0 1 5}$ & $\mathbf{2 0 1 6}$ & $\mathbf{2 0 1 7}$ & $\mathbf{2 0 1 8}$ & $\mathbf{2 0 1 9}$ \\
\hline \hline Januari & 3.074 .589 & 3.100 .665 & 3.620 .900 & 3.910 .450 & 4.006 .225 \\
\hline Februari & 3.188 .867 & 3.225 .680 & 3.611 .775 & 3.929 .475 & 4.108 .225 \\
\hline Maret & 3.292 .490 & 3.020 .865 & 3.619 .780 & 3.980 .025 & 4.011 .740 \\
\hline April & 3.366 .622 & 3.240 .765 & 3.890 .765 & 3.990 .775 & 4.018 .718 \\
\hline Mei & 3.070 .179 & 3.130 .960 & 3.690 .850 & 3.927 .125 & 4.008 .247 \\
\hline Juni & 3.480 .327 & 3.345 .600 & 3.560 .850 & 3.780 .825 & 4.005 .345 \\
\hline Juli & 3.079 .453 & 3.008 .950 & 3.670 .865 & 3.990 .725 & 4.012 .610 \\
\hline Agustus & 3.451 .894 & 3.512 .097 & 3.709 .615 & 3.912 .175 & 4.018 .932 \\
\hline September & 3.318 .749 & 3.420 .955 & 3.690 .785 & 3.931 .875 & 4.008 .322 \\
\hline Oktober & 3.417 .462 & 3.502 .898 & 3.792 .735 & 3.928 .943 & 4.147 .275 \\
\hline November & 3.971 .508 & 3.810 .700 & 3.769 .974 & 3.920 .925 & 4.019 .214 \\
\hline Desember & 3.198 .695 & 3.920 .350 & 3.680 .860 & 3.980 .265 & 4.822 .550 \\
\hline Total Pertahun & $\mathbf{3 9 . 9 1 0 . 8 3 5}$ & $\mathbf{4 0 . 2 4 0 . 4 8 5}$ & $\mathbf{4 4 . 3 0 9 . 7 5 4}$ & $\mathbf{4 7 . 1 8 3 . 5 8 3}$ & $\mathbf{4 9 . 1 8 7 . 4 0 3}$ \\
\hline Total Lima Tahun & \multicolumn{5}{|c|}{$\mathbf{2 2 0 . 8 3 2 . 0 6 0}$} \\
\hline Rata-rata & \multicolumn{7}{|c|}{$\mathbf{4 4 . 1 6 6 . 4 1 2}$} \\
\hline
\end{tabular}

Tabel 5. Rincian kebutuhan Stabilizer periode 2015-2019

\begin{tabular}{|l|r|r|r|r|r|}
\hline \multirow{3}{*}{ Bulan } & \multicolumn{5}{|c|}{ Tahun } \\
\cline { 2 - 6 } & \multicolumn{1}{|c|}{$\mathbf{2 0 1 5}$} & \multicolumn{1}{c|}{$\mathbf{2 0 1 6}$} & \multicolumn{1}{c|}{$\mathbf{2 0 1 7}$} & \multicolumn{1}{c|}{$\mathbf{2 0 1 8}$} & \multicolumn{1}{c|}{$\mathbf{2 0 1 9}$} \\
\hline \hline Januari & 744 & 1.864 & 2.287 & 1.991 & 2.143 \\
\hline Februari & 956 & 1.741 & 1.904 & 2.052 & 2.367 \\
\hline Maret & 860 & 1.654 & 1.907 & 1.864 & 2.286 \\
\hline April & 867 & 1.745 & 2.128 & 2.177 & 2.424 \\
\hline Mei & 902 & 1.832 & 1.876 & 2.091 & 2.819 \\
\hline Juni & 943 & 1.645 & 1.978 & 1.893 & 1.963 \\
\hline Juli & 858 & 1.774 & 1.236 & 2.091 & 2.281 \\
\hline Agustus & 931 & 1.854 & 1.674 & 1.872 & 2.371 \\
\hline September & 843 & 1.845 & 1.865 & 2.093 & 1.862 \\
\hline Oktober & 973 & 1.753 & 1.985 & 2.344 & 2.451 \\
\hline November & 890 & 1.866 & 1.674 & 1.882 & 2.273 \\
\hline Desember & 850 & 1.742 & 1.997 & 1.912 & 1.984 \\
\hline Total Pertahun & $\mathbf{1 0 . 6 1 7}$ & $\mathbf{2 1 . 3 1 5}$ & $\mathbf{2 2 . 5 1 1}$ & $\mathbf{2 4 . 2 6 2}$ & $\mathbf{2 7 . 2 2 4}$ \\
\hline Total Lima Tahun & \multicolumn{7}{|c|}{} & $\mathbf{1 0 5 . 9 2 9}$ \\
\hline Rata-rata & \multicolumn{7}{|c|}{} \\
\hline
\end{tabular}

Tabel 6. Rincian kebutuhan PVC 71 periode 2015-2019

\begin{tabular}{|c|c|c|c|c|c|}
\hline \multirow{2}{*}{ Bulan } & \multicolumn{5}{|c|}{ Tahun } \\
\hline & 2015 & 2016 & 2017 & 2018 & 2019 \\
\hline \begin{tabular}{|l} 
Januari \\
\end{tabular} & 1.004 .800 & 1.097 .980 & 1.380 .825 & 1.600 .725 & 1.979 .225 \\
\hline Februari & 1.187 .580 & 1.379 .070 & 1.380 .565 & 1.740 .665 & 1.980 .875 \\
\hline Maret & 1.175 .000 & 1.405 .660 & 1.322 .075 & 1.745 .750 & 1.941 .575 \\
\hline April & 1.178 .930 & 1.354 .790 & 1.317 .856 & 1.748 .965 & 1.942 .725 \\
\hline Mei & 1.109 .200 & 1.210 .670 & 1.485 .350 & 1.740 .775 & 1.965 .825 \\
\hline Juni & 1.110 .900 & 1.306 .530 & 1.208 .664 & 1.535 .625 & 1.747 .825 \\
\hline Juli & 984.490 & 1.206 .350 & 1.490 .775 & 1.760 .725 & 1.980 .925 \\
\hline Agustus & 1.220 .080 & 1.227 .420 & 1.420 .965 & 1.770 .825 & 1.931 .775 \\
\hline September & 1.270 .410 & 1.288 .940 & 1.468 .779 & 1.738 .250 & 1.981 .175 \\
\hline Oktober & 1.285 .500 & 1.224 .450 & 1.385 .225 & 1.776 .548 & 2.122 .550 \\
\hline November & 1.043 .250 & 1.306 .390 & 1.482 .450 & 1.787 .460 & 2.192 .722 \\
\hline Desember & 1.230 .110 & 1.407 .780 & 1.475 .610 & 1.785 .325 & 2.108 .925 \\
\hline Total Pertahun & 13.800 .250 & 15.416 .030 & 16.819 .139 & 20.731 .638 & 23.876 .122 \\
\hline Total Lima Tahun & & & & & 90.643 .179 \\
\hline Rata-rata & & & & & 18.128 .636 \\
\hline
\end{tabular}

Hasil Analisys tren kebutuhan bahan baku selama periode 2015-2019 mengalami kenaikan setiap tahunya dapat dilihat pada gambar 5 . Sebagai berikut:

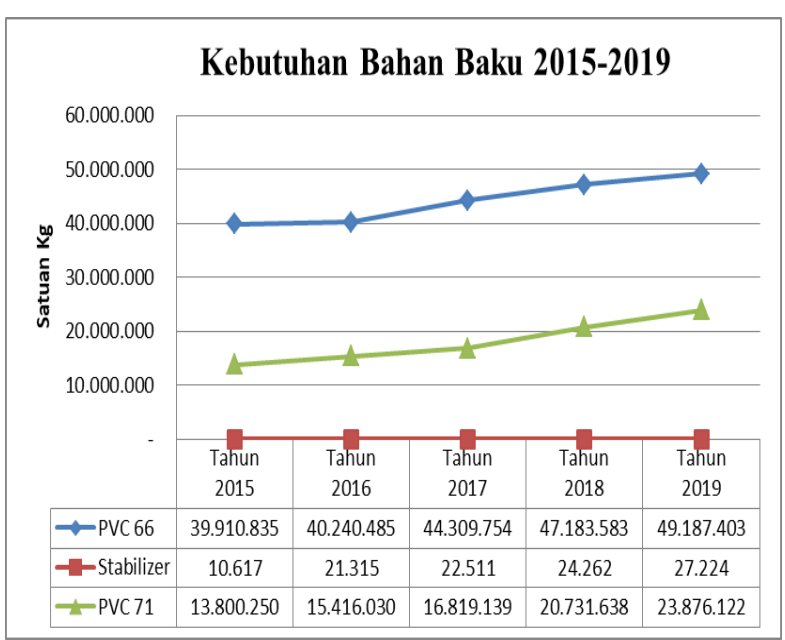

Gambar 7. Tren kebutuhan bahan baku

Berikut ini biaya pemesanan bahan baku periode 2015-2019 yang akan digunakan untuk menghitung economic order quantity, dapat dilihat pada tabel di bawah ini: 
Tabel 7. Rincian biaya pemesanan PVC 66

\begin{tabular}{|c|c|c|c|c|c|c|}
\hline \multirow{2}{*}{ No } & \multirow{2}{*}{ Biaja } & \multicolumn{5}{|c|}{ Bahan baku PVC 66} \\
\hline & & 2015 & 2016 & 2017 & 2018 & 2019 \\
\hline & Internet & 3.050 .000 & 3.350 .000 & 3.615 .000 & 3.802 .500 & 3.950 .000 \\
\hline & Telepon & 1.600 .000 & 1.750 .000 & 1.975 .000 & 2.125 .000 & 2.205 .000 \\
\hline & Administrasi & 150.000 .000 & 180.0000 .000 & 210.000 .000 & 240.000 .000 & 270.000 .000 \\
\hline Tot & & 154.650 .000 & 185.1000 .000 & 215.590 .000 & 245.927.500 & 276.155 .000 \\
\hline & de Pembelian & 266 & 268 & 295 & 315 & 328 \\
\hline & a Setiap Pesan & 581.391 & 690.672 & 730.814 & 780.722 & 841.936 \\
\hline
\end{tabular}

Tabel 8. Rincian biaya pemesanan Stabilizer

\begin{tabular}{|r|l|r|l|l|l|l|}
\hline \multirow{2}{*}{ No } & \multirow{2}{*}{ Biaya } & \multicolumn{5}{|c|}{ Bahan baku Stabilizer } \\
\cline { 3 - 7 } & & \multicolumn{1}{c|}{2015} & \multicolumn{1}{c|}{$\mathbf{2 0 1 6}$} & \multicolumn{1}{c|}{2017} & \multicolumn{1}{l|}{2018} & \multicolumn{1}{c|}{$\mathbf{2 0 1 9}$} \\
\hline 1 & Internet & 1.100 .000 & 1.250 .000 & 1.400 .000 & 1.575 .000 & 1.610 .000 \\
\hline 2 & Telepon & 900.000 & 1.050 .000 & 1.100 .000 & 1.250 .000 & 1.320 .000 \\
\hline 3 & Administrasi & 2.750 .000 & 4.500 .000 & 4.900 .000 & 7.400 .000 & 7.425 .000 \\
\hline Total & 4750.000 & 6.800 .000 & 7.400 .000 & 10.225 .000 & 10.355 .000 \\
\hline Periode Pembelian & 6 & 7 & 8 & 8 & 9 \\
\hline Biaya Setiap Pesan & 791.667 & 971.429 & 925.000 & 1.278 .125 & 1.150 .556 \\
\hline
\end{tabular}

Tabel 9. Rincian biaya pemesanan PVC 71

\begin{tabular}{|r|l|r|r|r|r|r|}
\hline \multirow{2}{*}{$N_{0}$} & \multirow{2}{*}{ Biaya } & \multicolumn{5}{|c|}{ Bahan baku PVC (71) } \\
\cline { 3 - 7 } & & \multicolumn{1}{c|}{$\mathbf{2 0 1 5}$} & \multicolumn{1}{c|}{$\mathbf{2 0 1 6}$} & \multicolumn{1}{c|}{$\mathbf{2 0 1 7}$} & \multicolumn{1}{c|}{$\mathbf{2 0 1 8}$} & \multicolumn{1}{c|}{$\mathbf{2 0 1 9}$} \\
\hline 1 & Internet & 2.500 .000 & 2.700 .000 & 3.100 .000 & 3.300 .000 & 3.500 .000 \\
\hline 2 & Telepon & 1.200 .000 & 1.400 .000 & 1.600 .000 & 1.800 .000 & 2.100 .000 \\
\hline 3 & Administrasi & 75.000 .000 & 90.000 .000 & 105.000 .000 & 120.000 .000 & 135.000 .000 \\
\hline \multicolumn{2}{|l|}{ Total } & 78.700 .000 & 105.600 .000 & 121.500 .000 & 145.100 .000 & 160.500 .000 \\
\hline Periode Pembelian & 138 & 154 & 168 & 207 & 238 \\
\hline Biaya Setiap Pesan & 570.290 & 685.714 & 723.214 & 700.966 & 674.370 \\
\hline
\end{tabular}

Biaya penyimpanan atau holding cost adalah biaya yang timbul dan ditangung oleh perusahaan akibat perawatan tempat penyimpanan. Perusahaan menentukan ketentuan biaya penyimpanan $2,5 \%$ dari harga per unit setiap bahan baku PVC Compound dapat dilihat pada Tabel 10 sebagai berikut:

Tabel 10. Biaya Penyimpanan

\begin{tabular}{|c|l|c|c|}
\hline No & Bahan baku & Harga Per Unit & $\begin{array}{c}\text { Biaya } \\
\text { Penyimpanan } \\
\mathbf{2 , 5 \%}\end{array}$ \\
\hline 1. & PVC 66 & Rp35.500 & Rp887,50 \\
\hline 2. & Stabilizer & Rp36.750 & Rp918,75 \\
\hline 3. & PVC 71 & Rp35.300 & Rp882,50 \\
\hline
\end{tabular}

\subsection{Proses Perhitungan Metode EOQ Bahan Baku PVC Compound Menggunakan POM-QM For Windows}

Langkah selanjutnya untuk menyelesaiakan perhitungan Metode EOQ menggunakan Tools teknologi informasi POM-QM For Windows V5.2, yaitu sebagai berikut:

1. Buka POM-QM For Windows V5.2 pilih module inventory.

2. Klik File Pilih New kemudian klik Economic Order Quantity (EOQ) Model.

3. Sehingga akan muncul tampilan baru, isi Title pilih dan klik OK

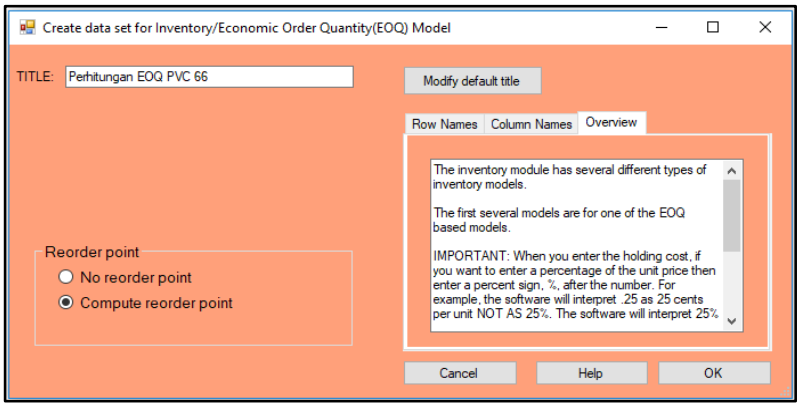

Gambar 8. Tampilan Create data set inventory

4. Masukan data untuk perhitungan dengan dengan lengkap seperti pada Gambar 9.

\begin{tabular}{|l|r|}
\hline 1.EOQ PVC 66 & Value \\
\hline Parameter & 39.910 .840 \\
\hline Demand rate(D) & 581.391 \\
\hline Setup/ordering cost(S) & $2,5 \%$ \\
\hline Holding/carrying cost(H) & 35.500 \\
\hline Unit cost & 0 \\
\hline Days per year or ... & 166.295 \\
\hline ...Daily demand rate(d) & 5 \\
\hline Lead time (in days) & 831.476 \\
\hline Safety stock &
\end{tabular}

Gambar 9. Tampilan Input data

5. Kemudian klik Solve untuk penyelesaian.

Berikut ini hasil perhitungan bahan baku :

1. Hasil perhitungan PVC 66 tahun 2015

Adapun hasil perhitungan Bahan baku PVC 66 pada tahun 2015 terlihat pada Gambar 10 Sebagai berikut: 


\begin{tabular}{|c|c|c|c|}
\hline Parameter & \begin{tabular}{l|l} 
Value \\
\end{tabular} & Parameter & Value \\
\hline Demand rate(D) & 39.910 .840 & Optimal order quantity $\left(Q^{*}\right)$ & $228.670,6$ \\
\hline Setup/Ordering cost(S) & 581.391 & Maximum IIventory Level(Imax) & $228.670,6$ \\
\hline Holding cost(H)@2,5\% & 887,5 & Average inventory & $114.335,3$ \\
\hline Unit cost & 35.500 & Orders per period(year) & 174,53 \\
\hline Days per year (D/d) & 240 & Annual Setup cost & 101.472 .600 \\
\hline Daly demand rate & 166.295 & Annual Holding cost & 101.472.600 \\
\hline Lead time (in days) & 5 & Annual Holding (safety stock) & 737.935 .000 \\
\hline \multirow[t]{4}{*}{ Safety stock } & 831.476 & Unit costs (PD) & 1.416.835.000.000 \\
\hline & & Total Cost & 1.417 .776 .000 .000 \\
\hline & & & \\
\hline & & Reorder point & 1.662 .951 units \\
\hline
\end{tabular}

Gambar 10. Hasil Perhitungan PVC 66 Tahun 2015

Hasil perhitungan di atas jumlah pemesanan optimal sebesar 228.670,60 Units periode pemesanan setiap tahun 175 kali, dengan biaya pemesana pertahun $\mathrm{Rp} 101.472 .600$, titik pemesanan kembali diketahui sebesar 1.666.95,00 Units.

2. Hasil perhitungan Stabilizer tahun 2015

Adapun hasil perhitungan Bahan baku Stabilizer pada tahun 2015 terlihat pada Gambar 11 Sebagai berikut:

\begin{tabular}{|c|c|c|c|}
\hline Parameter & Value & Parameter & Value \\
\hline Demand rate(D) & 18.742 & Optimal order quantity $\left(Q^{*}\right)$ & $5.683,23$ \\
\hline Setup/Ordering cost(S) & 791.667 & Maximum Inventory Level (Imax) & $5.683,23$ \\
\hline Holding cost(H)@2,5\% & 918,75 & Average inventory & $2.841,62$ \\
\hline Unit cost & 36.750 & Orders per period(year) & 3,3 \\
\hline Days per year $(D / d)$ & 240,28 & Annual Setup cost & $2.610 .736,0$ \\
\hline Daily demand rate & 78 & Annual Holding cost & $2.610 .736,0$ \\
\hline Lead time (in days) & 5 & Annual Holding (safety stock) & $358.312,5$ \\
\hline \multirow[t]{4}{*}{ Safety stock } & 390 & Unit costs (PD) & 688.768 .500 \\
\hline & & Total Cost & 694.348 .300 \\
\hline & & & \\
\hline & & Reorder point & 780 units \\
\hline
\end{tabular}

Gambar 11. Hasil Perhitungan Stabilizer Tahun 2015

Hasil perhitungan di atas jumlah pemesanan optimal sebesar 5.683,23 Units, periode pemesanan setiap tahun 3 kali, dengan biaya pemesana pertahun $\mathrm{Rp} 2.610 .736,00$, titik pemesanan kembali diketahui sebesar 780,00 Units.

1. Hasil perhitungan PVC 71 tahun 2015

Adapun hasil perhitungan Bahan baku Stabilizer pada tahun 2015 terlihat pada Gambar 12 Sebagai berikut:

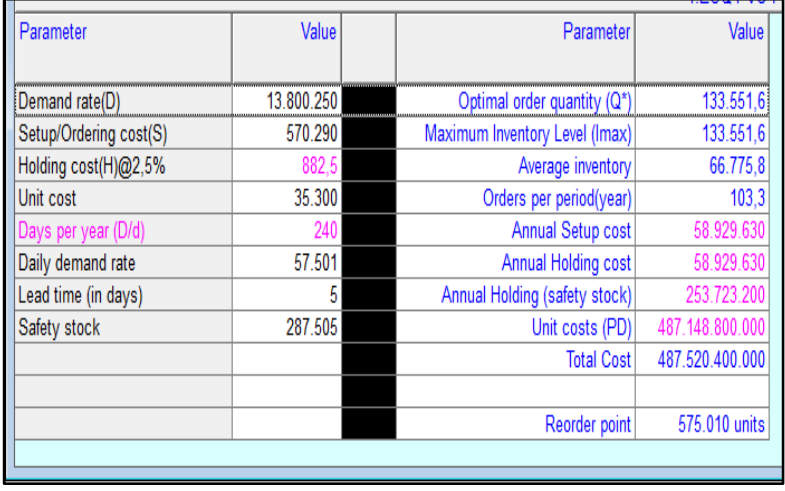

Gambar 12. Hasil Perhitungan PVC 71 Tahun 2015

Hasil perhitungan di atas jumlah pemesanan optimal sebesar 133.551,6 Units, periode pemesanan setiap tahun 103 kali, dengan biaya pemesana pertahun Rp 58.929.00, titik pemesanan kembali diketahui sebesar 575.010,00 Units.

\subsection{Hasil Perhitungan POM-QM For Windows dibandingan Dengan Kebijakan Perusahaan Dengan}

Berikut ini merupakan hasil perbandingan antara kebijakan perusahaan dengan perhitungan POM-QM For Windows.

1. Hasil Perbandingan Bahan baku PVC 66

Tabel 11. Hasil Perbandingan PVC 66

\begin{tabular}{|c|c|c|c|c|c|c|}
\hline \multirow[b]{2}{*}{ Tahun } & \multicolumn{2}{|c|}{ Kebijakan Perusahaan } & \multicolumn{2}{|c|}{ Hasil Perhitungan P0M QM } & \multirow[b]{2}{*}{ Selisih } & \multirow[b]{2}{*}{$\begin{array}{c}\text { Persentase } \\
\text { Selisih }\end{array}$} \\
\hline & $\begin{array}{c}\text { Optimal } \\
\text { order } \\
\text { quantity } \\
\left(Q^{*}\right)(\mathrm{Kg})\end{array}$ & $\begin{array}{c}\text { Annual Setup cost } \\
\text { (Rp) }\end{array}$ & $\mid \begin{array}{c}\text { Optimal order } \\
\text { quantity }\left(Q^{*}\right) \\
(\mathrm{Kg})\end{array}$ & $\begin{array}{c}\text { Annual Setup } \\
\operatorname{cost}(\mathrm{Rp})\end{array}$ & & \\
\hline 2015 & - & $154.650 .000,00$ & 228670,60 & $101.472 .600,00$ & $53.177 .400,00$ & $34 \%$ \\
\hline 2016 & - & $185.100 .000,00$ & 250264,00 & $111.054,600,00$ & $74.045 .400,00$ & $40 \%$ \\
\hline 2017 & - & $215.590 .000,00$ & 270136,90 & \begin{tabular}{|l}
$119.873 .200,00$ \\
\end{tabular} & $95.716 .800,00$ & $44 \%$ \\
\hline 2018 & . & $245.927 .500,00$ & 288120,70 & $127.853 .600,00$ & $118.073 .900,00$ & $48 \%$ \\
\hline 2019 & - & $276.155 .000,00$ & 305490,20 & $135.561 .300,00$ & $140.593 .700,00$ & $51 \%$ \\
\hline & $215.484 .500,00$ & $268.536,48$ & $119.163 .060,00$ & $96.321 .440,00$ & $44 \%$ \\
\hline
\end{tabular}

Hasil perhitungan di atas Annual Setup Cost kebijakan perusahaan dengan rata-rata selama lima tahun $\mathrm{Rp}$ 215.484.500,00 sedangkan hasil perhitungan POM-QM For Windows dengan ratarata $\mathrm{Rp}$ 119.163.060,00 selisih biaya $\mathrm{Rp}$ $96.321 .440,00$ atau menghemat biaya rata-rata $44 \%$ lebih rendah dibandingakan dengan kebijakan perusahaan, Optimal order setiap pemesanan yaitu $268.536 .48 \mathrm{Kg}$. 
2. Hasil perbandingan Bahan baku Stabilizer

Tabel 12. Hasil Perbandingan Stabilizer

\begin{tabular}{|c|c|c|c|c|c|c|}
\hline \multirow[b]{2}{*}{ Tahun } & \multicolumn{2}{|c|}{ Kebijakan Perusahaan } & \multicolumn{2}{|c|}{ Hasil Perhitungan POM QM } & \multirow[b]{2}{*}{ Selisih } & \multirow[b]{2}{*}{$\begin{array}{c}\text { Persentase } \\
\text { Selisih }\end{array}$} \\
\hline & $\begin{array}{c}\text { Optimal } \\
\text { order } \\
\text { quantity } \\
\left(Q^{*}\right)(\mathrm{Kg}) \\
\end{array}$ & $\begin{array}{c}\text { Annual Setup cost } \\
\text { (Rp) }\end{array}$ & $\mid \begin{array}{c}\text { Optimal order } \\
\text { quantity }\left(Q^{*}\right) \\
(\mathrm{Kg})\end{array}$ & $\begin{array}{c}\text { Annual Setup } \\
\text { cost (Rp) }\end{array}$ & & \\
\hline 2015 & . & $4.750 .000,00$ & $5.683,23$ & $2.610 .736,00$ & $2.139 .264,00$ & $45 \%$ \\
\hline 2016 & - & $6.800 .000,00$ & $6.713,74$ & $3.084 .124,00$ & $3.715 .876,00$ & $55 \%$ \\
\hline 2017 & - & $7.400 .000,00$ & $6.732,63$ & $3.092 .801,00$ & $4.307 .199,00$ & $58 \%$ \\
\hline 2018 & - & $10.225 .000,00$ & $8.216,11$ & $3.774 .276,00$ & $6.450 .724,00$ & $63 \%$ \\
\hline 2019 & - & $10.355 .000,00$ & $8.257,45$ & $3.793 .268,00$ & $6.561 .732,00$ & $63 \%$ \\
\hline & & $7,906,000,00$ & $7.120,63$ & $3.271,041,00$ & $4.634,959,00$ & $57 \%$ \\
\hline
\end{tabular}

Hasil perhitungan di atas Annual Setup Cost kebijakan perusahaan dengan rata-rata selama lima tahun $\mathrm{Rp}$ 7.906.000,00 sedangkan hasil perhitungan POM-QM For Windows dengan ratarata $\mathrm{Rp}$ 3.271.041,00 selisih biaya $\mathrm{Rp}$ 4.634.959,00 atau menghemat biaya rata-rata 57\% lebih rendah dibandingakan dengan kebijakan perusahaan, Optimal order setiap pemesanan yaitu 7.120,63 Kg.

3. Hasil perbandingan Bahan bakuPVC 71

Tabel 13. Hasil Perbandingan PVC 71

\begin{tabular}{|c|c|c|c|c|c|c|}
\hline \multirow{2}{*}{ Tahun } & \multicolumn{2}{|c|}{ Kebijakan Perusahaan } & \multicolumn{2}{|c|}{ Hasil Perhitungan POMQM } & \multirow{2}{*}{ Selisih } & \multirow{2}{*}{\begin{tabular}{|c} 
Persentase \\
Selisih
\end{tabular}} \\
\hline & $\begin{array}{c}\text { Optimal } \\
\text { order } \\
\text { quantity } \\
\left(Q^{*}\right)(\mathrm{Kg}) \\
\end{array}$ & $\begin{array}{c}\text { Annual Setup cost } \\
\text { (Rp) }\end{array}$ & $\mid \begin{array}{c}\text { Optimal order } \\
\text { quantity }\left(\mathrm{Q}^{*}\right) \\
(\mathrm{Kg})\end{array}$ & $\begin{array}{l}\text { Annual Setup } \\
\operatorname{cost}(\mathrm{Rp})\end{array}$ & & \\
\hline 2015 & - & $78.700 .000,00$ & $133.551,60$ & $58.929 .630,00$ & $19.770 .370,00$ & $25 \%$ \\
\hline 2016 & - & $105.600 .000,00$ & $154.780,20$ & $68.296 .770,00$ & $37.303 .230,00$ & $35 \%$ \\
\hline 2017 & - & $121.500 .000,00$ & $166.032,40$ & $73.261 .820,00$ & $48.238 .180,00$ & $40 \%$ \\
\hline 2018 & - & $145.100 .000,00$ & $181.477,60$ & $80.076 .980,00$ & $65.023 .020,00$ & $45 \%$ \\
\hline 2019 & & $160.500 .000,00$ & $191.075,30$ & $84.311 .970,00$ & $76.188 .030,00$ & $47 \%$ \\
\hline Rata & ta-rata & $122.280 .000,00$ & $165.383,42$ & 72.975.434,00 & $49.304 .566,00$ & $38 \%$ \\
\hline
\end{tabular}

Hasil perhitungan di atas Annual Setup Cost kebijakan perusahaan dengan rata-rata selama lima tahun $\mathrm{Rp}$ 122.280.000,00 sedangkan hasil perhitungan POM-QM For Windows dengan ratarata $\mathrm{Rp} 72.975 .434,00$ selisih biaya $\mathrm{Rp}$ 49.304.566.00 atau menghemat biaya rata-rata $38 \%$ lebih rendah dibandingakan dengan kebijakan perusahaan, Optimal order setiap pemesanan yaitu $165.383,42 \mathrm{Kg}$.

\section{Kesimpulan}

Berdasarkan hasil hasil penelitian di PT.Sinarmonas Industries maka dapat ditarik kesimpulan sebagai berikut:

1. Hasil klasifikasi yang dihasilkan dari perhitungan metode ABC Analisys menggunakan POM-QM For Windows terdapat tiga bahan baku yang masuk kategori A yaitu bahan baku PVC 66, Stabilizer, dan PVC 71 membutuhkan monitoring sangat ketat.

2. Perusahaan dapat menghemat biaya biaya pemesanan atau Annual Ordering Cost bahan baku PVC 66 menghemat biaya rata-rata $\mathrm{Rp}$ 96.321.440,00 atau 44\%, bahan baku Stabilizer menghemat biaya rata-rata $\mathrm{Rp}$ 4.634.959,00 atau 57\%, bahan baku PVC 71 menghemat biaya rata-rata Rp 49.304.566.00 atau 38\%.

3. Hasil perhitungan menunjukan Optimal order quantity bahan baku PVC $66268.536,48 \mathrm{Kg}$, bahan baku Stabilizer 7.120,63 Kg, bahan baku PVC 71 165.383,42 Kg. Reorder point bahan baku PVC $661.840 .297,60 \mathrm{Kg}$, bahan baku Stabilizer $950,00 \mathrm{Kg}$, bahan baku PVC 71 $755.359,80 \mathrm{Kg}$.

\section{Saran}

Berdasarkan hasil penelitian kesimpulan yang diperoleh dalam penelitian ini, maka peneliti mengajuan saran sebagai bahan pertimbangan, yaitu sebagai berikut:

1. Perusahaan perlu mempertimbangkan mengklasifikasikan bahan baku dengan cara menerapkan Analisys ABC berdasarkan tingkat prioritas penyerapan modal.

2. Perusahaan sebaiknya mempertimbangkan untuk menggunakan POM-QM For Windows untuk penyelesaian manajemen produksi dan operasi.

3. Peneliti berikutnya dapat melakukan penelitian yang berbeda dalam manajemen operasi tidak hanya POM-QM For Windows agar dapat dikembangkan dan mendapat temuan baru.

\section{Referensi}

Apriyani, N., \& Muhsin, A. (2017). Analisis Pengendalian Persediaan Bahan Baku Dengan Metode Economic Order Quantity Dan Kanban Pada PT Adyawinsa Stamping Industries. Jurnal Optimasi Sistem Industri, 10(2), 128-142. 
Nisa , C. (2019). Optimasi Hasil Produksi Genteng Menggunakan Goal Programming Sebagai Monograf. Pendidikan MIPA

Roni , S. (2016). Pengendalian Persediaan Bahan Baku Menggunakan Activity Based Costing (ABC) Analisis Pada PT Besimindo Andalas Semesta. JOM FEKON, 3(1), 14-27.

Jay, H., \& Barry, R. (2010). Operations Management. In Sungkono, \& Criswan, Manajemen Operasi (p. 9). Indonesia: Salemba Empat.

Ramadhany, F. F. (2017). Analisis Pernerapan Sistem Manajemen Mutu ISO 9001:2015 Dalam Menunjang Pemasaran. Jurnal Administrasi Bisnis, 53(1), 31-38.

Weiss, H. J. (2011). POM QM for Windows Software for Decision Sciences. Northwestern University: Pearson Education, Inc. 